\title{
Tumor budding in upper gastrointestinal carcinomas
}

\author{
Viktor H. Koelzer ${ }^{1,2}$, Rupert Langer ${ }^{1,2}$, Inti Zlobec ${ }^{2}$ and Alessandro Lugli ${ }^{1,2}$ * \\ ${ }^{1}$ Clinical Pathology Division, Institute of Pathology, University of Bern, Bern, Switzerland \\ 2 Translational Research Unit, Institute of Pathology, University of Bern, Bern, Switzerland
}

\section{Edited by:}

Carlo Senore, AOU S Giovanni

Battista - CPO Piemonte, Italy

\section{Reviewed by:}

Parham Minoo, University of Calgary,

Canada

Elizabeth J. Ryan, St Vincent's

University Hospital, Ireland

Carlo Senore, AOU S Giovanni

Battista - CPO Piemonte, Italy

${ }^{*}$ Correspondence:

Alessandro Lugli, Institute of Pathology, University of Bern,

Murtenstrasse 31, CH-3010 Bern,

Switzerland

e-mail: alessandro.lugli@

pathology.unibe.ch
The basis of personalized medicine in oncology is the prediction of an individual's risk of relapse and death from disease. The presence of tumor budding (TB) at the tumor-host interface of gastrointestinal cancers has been recognized as a hallmark of unfavorable disease biology. TB is defined as the presence of dedifferentiated cells or small clusters of up to five cells at the tumor invasive front and can be observed in aggressive carcinomas of the esophagus, stomach, pancreas, ampulla, colon, and rectum. Presence of TB reproducibly correlates with advanced tumor stage, frequent lymphovascular invasion, nodal, and distant metastasis. The UICC has officially recognizedTB as additional independent prognostic factor in cancers of the colon and rectum. Recent studies have also characterized TB as a promising prognostic indicator for clinical management of esophageal squamous cell carcinoma, adenocarcinoma of the gastro-esophageal junction, and gastric adenocarcinoma. However, several important issues have to be addressed for application in daily diagnostic practice: (1) validation of prognostic scoring systems forTB in large, multi-center studies, (2) consensus on the optimal assessment method, and (3) inter-observer reproducibility. This review provides a comprehensive analysis of TB in cancers of the upper gastrointestinal tract including critical appraisal of perspectives for further study.

Keywords: gastrointestinal cancer, gastric cancer, esophageal cancer, tumor microenvironment, tumor budding, prognostic factor, epithelial-mesenchymal transition

\section{INTRODUCTION}

The foundation of personalized oncological therapy is the prediction of an individual's risk of relapse and death from disease. Staging of tumors is performed according to the AJCC/UICC TNM classification (1). Following these internationally accepted guidelines, therapy decisions are made based on the anatomic extent of the tumor as determined by clinical, radiographic, and pathologic staging. In carcinomas of the upper gastrointestinal tract, we know that most patients with early invasive disease can expect a good prognosis and consequently advocate surgical or endoscopic resection as standard of care, while patients with locally advanced tumors or nodal metastasis are treated with multimodality therapy (2). Treatment decisions carry severe consequences for the patient. Precise risk assessment is therefore of central importance to balance benefit and overtreatment.

Following the TNM classification, patients with carcinomas of the upper gastrointestinal tract can be assigned to one of five main stages $(1,3)$. However, in the light of precision medicine and molecular pathology, risk stratification based only on the T, N, M, $\mathrm{L}, \mathrm{V}$, and $\mathrm{R}$ classifiers has to be viewed as approximate. In cancers of the upper gastrointestinal tract, we know that unexpected adverse clinical outcomes can be observed in patients even with early-stage disease $(4,5)$. Additional prognostic indicators based on tumor and host characteristics are therefore needed to find a precision approach. In particular, tumor-related factors found in the microenvironment may centrally impact patient prognosis. Recent studies highlight that epithelial tumors undergo mesenchymal transition (EMT) in the tumor microenvironment, allowing dissociative growth, migration, and lysis of stromal components
(6-8). In carcinomas of the gastrointestinal tract, the visible correlate of cells undergoing EMT is thought to be the presence of single cells or small clusters of up to five cells in the tumor stroma ahead of the invasive front, termed tumor budding (TB) $(6,7,9,10)$ (Figure 1). It is important to note that tumor buds can be quantified on the histologic slide to provide a TB score, which correlates with tumor aggressiveness. The prognostic value of $\mathrm{TB}$ has been established in a large number of independent retrospective studies for squamous cell carcinoma (SCC) (11-15) and adenocarcinoma of the esophagus (16-19), stomach $(20,21)$, colon (22-25), and rectum (26-29). Importantly, TB is officially recognized as an additional prognostic factor by the UICC for colorectal cancer and is listed by the European (30) and Japanese (31) guidelines for colorectal cancer screening and diagnosis as well as the guidelines of the European Society for Medical Oncology (ESMO) (32). Further, TB has recently been listed as a non-core data item by the European consensus conference colon and rectum (EURECCA), highlighting the increased use of this feature in clinical practice (33).

Biologically, tumor buds may transiently acquire a mesenchymal phenotype due to loss of E-cadherin expression and nuclear translocation of $\beta$-catenin leading to activation of WNT signaling $(6,34)$. Upregulation of metalloproteinases, urokinase receptor, and cathepsin may contribute to an increased migratory capacity and stromal invasion $(35,36)$. It has been suggested that tumor buds may resist both apoptosis and anoikis following the detachment from the primary tumor due to upregulation of anti-apoptotic proteins such as RAF-kinase inhibitor protein (RKIP) and caspase-3 deficiency (37-39). Further, tumor buds 


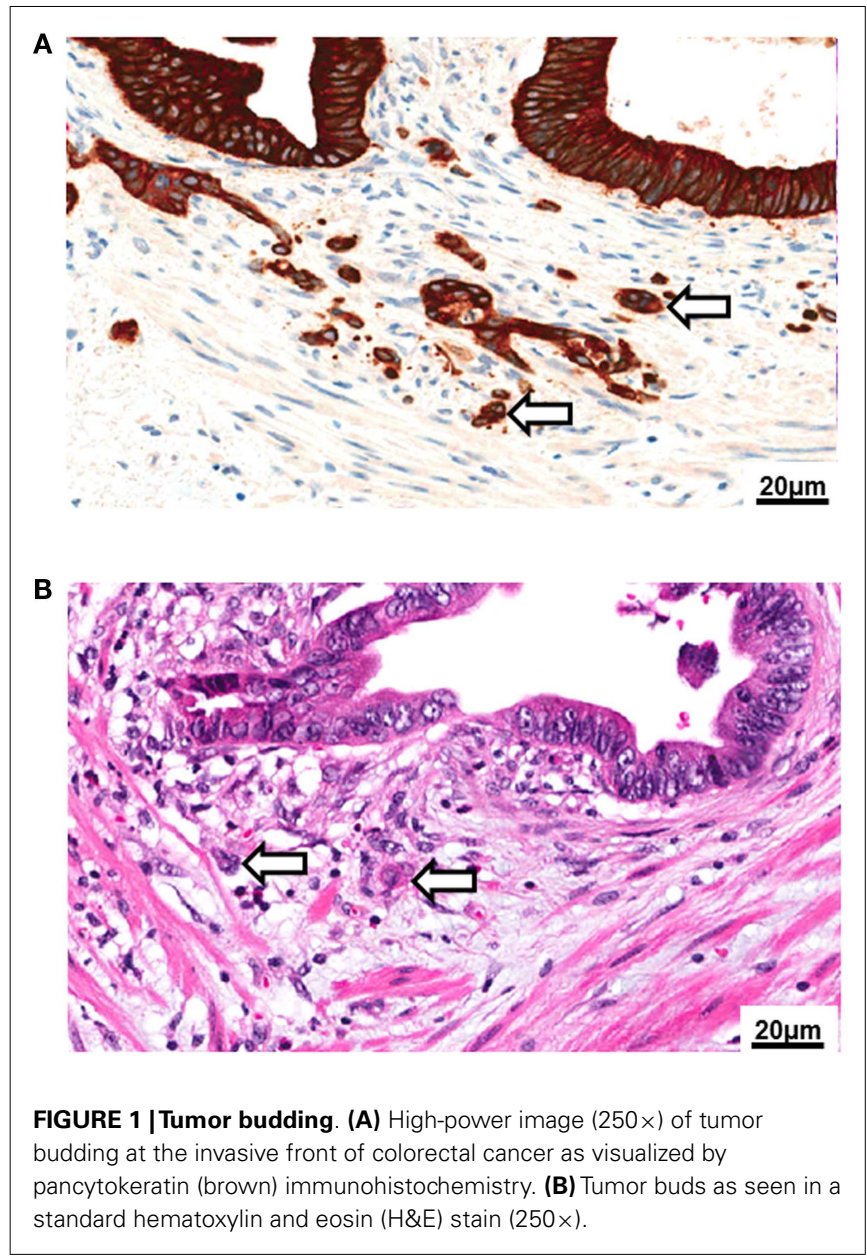

exhibit a low proliferative activity, which is in line with their migratory phenotype $(38,40)$. Taken together, these features may explain an increased resistance of tumor buds to chemo- and radiotherapy. Indeed, high-grade TB has been shown to be a highly specific indicator of poor response to radiotherapy in rectal cancer patients (41). As immunogenic cell death also entails the induction of apoptosis, this may also indicate an increased resistance to immunotherapeutic agents. Few studies have investigated the immunogenicity of tumor buds, but it has been suggested that loss of MHC-I expression could be a frequent feature in cancer initiating cells (42). CD8+ T-cells are frequent in the tumor microenvironment (43), yet may not be able to efficiently recognize tumor buds if MHC-I is lost. Interestingly, tumor buds may also possess stem cell like features, as suggested by an increased expression of ABCG-5 protein (44). These stem cell characteristics may allow cancer initiation at distant sites (Figure 2).

The formation of tumor buds by solid tumors may therefore represent an important first step toward metastasis. Interestingly, the histopathologist can visualize this step and make this feature accessible as a prognostic indicator for clinical management. In comparison to tumor grade, which has shown poor inter-observer reproducibility, the quantitative assessment of $\mathrm{TB}$ holds a definite advantage, just as mitoses are counted within a defined visual field for the histopathological reporting of the BRE-score score

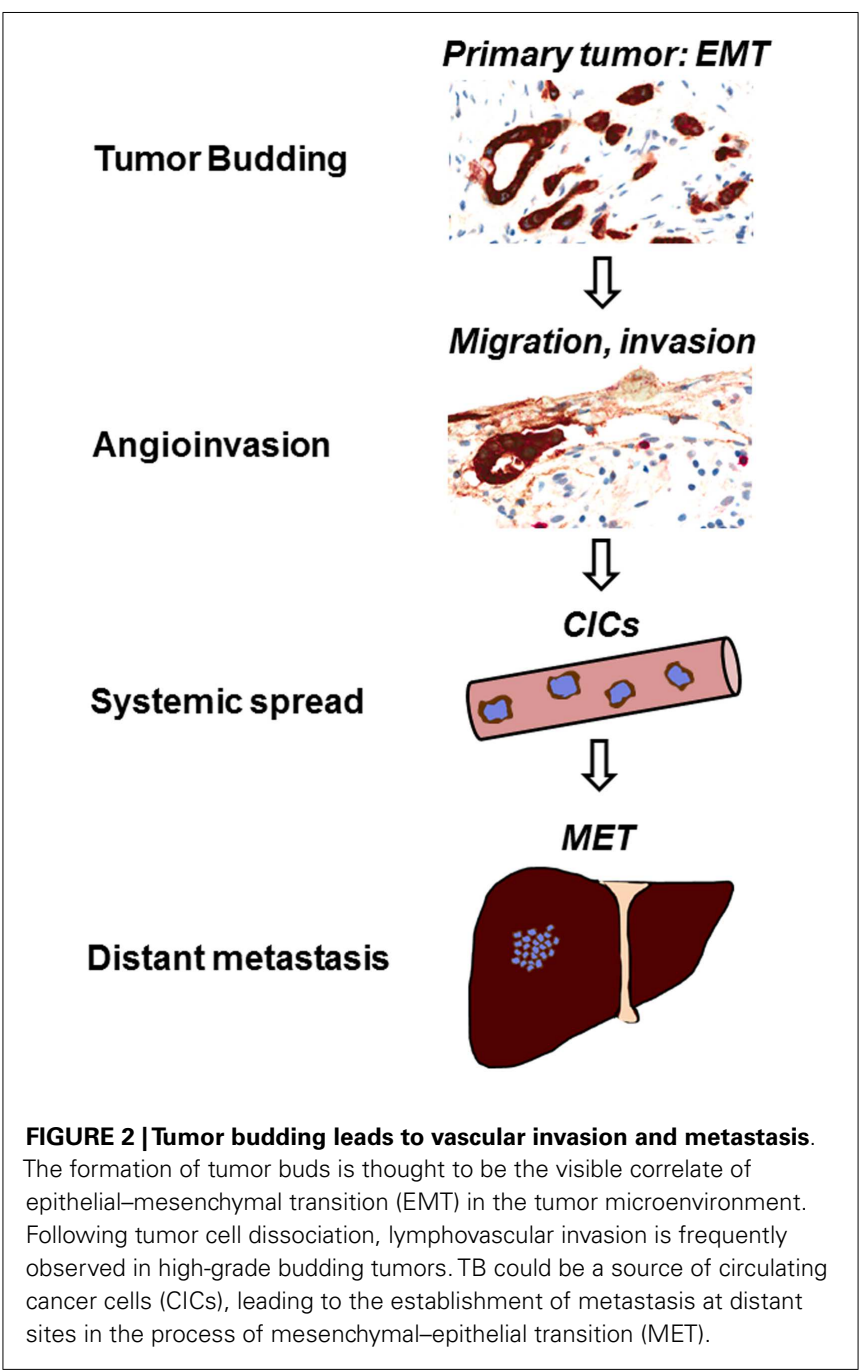

in breast cancer, tumor buds can be directly quantified under the microscope and reported as a quantitative feature. However, a broad spectrum of methods has been recommended for the assessment of TB in daily diagnostic practice. Morodomi (45) and Hase (46) have proposed a qualitative assessment based on the observers' impression of TB as present or absent (Morodomi), none/mild or moderate/severe (Hase). Nakamura and colleagues recommend semi-quantitative assessment of the proportion of the invasive front with TB $(23,47)$. This highly subjective methodology is contrasted by quantitative scoring methods as illustrated by Ueno (22, 48), Wang (24), Ono (49), Park (50), Lugli (51), Ohike (52), and Karamitopoulou (25). A central advantage to counting tumor buds is that quantitative scores tend to have a much higher inter-observer reproducibility (53) (Table 1).

Taken together, high-grade $\mathrm{TB}$ in gastrointestinal carcinomas could be a general indicator of aggressive clinicopathological behavior with importance for individualized risk assessment. While many studies have addressed TB in colon and rectal carcinoma, a uniting perspective on TB in carcinomas of the upper gastrointestinal tract has so far not been attempted. Subject of this review is therefore to provide a comprehensive overview on 
Table 1 | Methods used for assessment of tumor budding.

\begin{tabular}{|c|c|c|c|c|c|}
\hline Reference & Method & Classification & Staining & Region & Area \\
\hline $\begin{array}{l}\text { Morodomi et al., } \\
1989 \text { (45) }\end{array}$ & Qualitative; subjective assessment of TB intensity & Present or absent & $H \& E$ & Invasive front & Entire invasive front \\
\hline Hase et al., 1993 (46) & Qualitative; subjective assessment of TB intensity & $\begin{array}{l}\text { None/mild (BD-1) } \\
\text { Moderate/severe (BD-2) }\end{array}$ & $H \& E$ & Invasive front & Entire invasive front \\
\hline Ono et al., 1996 (49) & $\begin{array}{l}\text { Quantitative; all cancer cells with a single or } \\
\text { solitary trabecular form with indistinct polarity } \\
\text { ("focal dedifferentiation units") counted along the } \\
\text { invasive front }(200 \times)\end{array}$ & $\begin{array}{l}\text { None (0 unit) } \\
\text { Mild (1-20 units) } \\
\text { Moderate ( } 21-50 \text { units) } \\
\text { Severe (>50 units) }\end{array}$ & $H \& E$ & Invasive front & Entire invasive front \\
\hline $\begin{array}{l}\text { Nakamura et al., } \\
2005 \text { (47) }\end{array}$ & $\begin{array}{l}\text { Semi-quantitative assessment of the proportion } \\
\text { of the invasive front with TB }\end{array}$ & $\begin{array}{l}\text { None, mild ( }<1 / 3 \text { with TB) } \\
\text { Marked ( }>2 / 3 \text { with TB) } \\
\text { Moderate ( } 1 / 3-2 / 3 \text { with TB) }\end{array}$ & $H \& E$ & Invasive front & Entire invasive front \\
\hline Park et al., 2005 (50) & $\begin{array}{l}\text { Quantitative assessment of TB; the number of } \\
\text { buds is counted in three fields assessed under } \\
\text { high-power }(200 \times) \text { in area of most intense TB } \\
\text { along invasive front. TB intensity is defined as } \\
\text { maximum number of buds within the three fields }\end{array}$ & Continuous score & $H \& E$ & Invasive front & $\begin{array}{l}\text { Entire invasive front } \\
\text { assessed under low } \\
\text { power, } 1 \text { field }(200 \times) \\
\text { counted }\end{array}$ \\
\hline $\begin{array}{l}\text { Nakamura et al., } \\
2008 \text { (23) }\end{array}$ & $\begin{array}{l}\text { Semi-quantitative assessment of the proportion } \\
\text { of the invasive front with TB }\end{array}$ & $\begin{array}{l}\text { None/mild (low-grade) } \\
\text { Moderate/marked } \\
\text { (high-grade) }\end{array}$ & $H \& E$ & Invasive front & Entire invasive front \\
\hline $\begin{array}{l}\text { Ueno et al., } 2002 \\
\text { (48) }\end{array}$ & $\begin{array}{l}\text { Quantitative; invasive front scanned at low power } \\
\text { to identify region with densest TB; buds are } \\
\text { counted in one HPF }\end{array}$ & $\begin{array}{l}\text { Low-grade ( }<10 \text { buds) } \\
\text { High-grade ( } \geq 10 \text { buds) }\end{array}$ & $H \& E$ & Invasive front & $0.385 \mathrm{~mm}^{2}$ \\
\hline $\begin{array}{l}\text { Ueno et al., } 2004 \\
\text { (22) }\end{array}$ & $\begin{array}{l}\text { Quantitative; invasive front scanned at low power } \\
\text { to identify region with densest TB; buds are } \\
\text { counted in one HPF }\end{array}$ & $\begin{array}{l}\text { Low-grade ( }<5 \text { buds) } \\
\text { High-grade ( } \geq 5 \text { buds) }\end{array}$ & $H \& E$ & Invasive front & $0.785 \mathrm{~mm}^{2}$ \\
\hline $\begin{array}{l}\text { Wang et al., } 2009 \\
(24)\end{array}$ & $\begin{array}{l}\text { Conventional method: quantitative; invasive front } \\
\text { scanned at low power to identify region with } \\
\text { densest TB; buds are then counted in } 5 \\
\text { high-power fields }\end{array}$ & $\begin{array}{l}\text { Low-grade ( }<50 \% \text { of HPFs } \\
\text { exceed the median bud } \\
\text { count of all fields) } \\
\text { High-grade ( } \geq 50 \% \text { of } \\
\text { HPFs exceed the median } \\
\text { bud count of all fields) }\end{array}$ & $H \& E$ & Invasive front & $0.94985 \mathrm{~mm}^{2}$ \\
\hline $\begin{array}{l}\text { Wang et al., } 2009 \\
(24)\end{array}$ & $\begin{array}{l}\text { Rapid method: quantitative; } 5 \text { HPFs are evaluated } \\
\text { for presence of TB }\end{array}$ & $\begin{array}{l}\text { Low-grade }(<50 \% \text { of HPFs } \\
\text { examined positive for TB) } \\
\text { High-grade ( } \geq 50 \% \text { of HPFs } \\
\text { examined positive for TB) }\end{array}$ & $H \& E$ & Invasive front & $0.94985 \mathrm{~mm}^{2}$ \\
\hline $\begin{array}{l}\text { Lugli et al., } 2009 \\
\text { (1HPF method) (51) }\end{array}$ & $\begin{array}{l}\text { Quantitative; } 1 \text { HPF counted in areas of } \\
\text { densest TB }\end{array}$ & $\begin{array}{l}\text { Low-grade ( }<10 \text { buds in } 1 \\
\text { HPF of highest density) } \\
\text { High-grade ( } \geq 10 \text { buds in } 1 \\
\text { HPF of highest density) }\end{array}$ & PanCK & Invasive front & $0.49 \mathrm{~mm}^{2}$ \\
\hline $\begin{array}{l}\text { Ohike et al., } 2010 \\
\text { (52) }\end{array}$ & $\begin{array}{l}\text { Semi-quantitative; budding foci are identified. } \\
\text { Buds are counted in one HPF of each focus as } \\
\text { specified by Ueno (48). A HPF is counted as } \\
\text { positive for TB when } 5 \text { or more tumor buds are } \\
\text { present }\end{array}$ & $\begin{array}{l}\text { Low budding ( } 0-2 \text { positive } \\
\text { fields) } \\
\text { High budding (three or } \\
\text { more budding fields) }\end{array}$ & $H \& E$ & Invasive front & $0.785 \mathrm{~mm}^{2} / \mathrm{HPF}$ \\
\hline
\end{tabular}


Table 1 | Continued

\begin{tabular}{|c|c|c|c|c|c|}
\hline Reference & Method & Classification & Staining & Region & Area \\
\hline $\begin{array}{l}\text { Karamitopoulou } \\
\text { et al., } 2013 \text { (10HPF } \\
\text { method) (25) }\end{array}$ & $\begin{array}{l}\text { Quantitative; } 10 \text { HPF counted in areas of } \\
\text { densest TB }\end{array}$ & $\begin{array}{l}\text { Low-grade }(<100 \text { buds } \\
\text { total in } 10 \text { HPFs of highest } \\
\text { density) } \\
\text { High-grade ( } \geq 100 \text { buds } \\
\text { total in } 10 \text { HPFs of highest } \\
\text { density) }\end{array}$ & PanCK & Invasive front & $\begin{array}{l}0.49 \mathrm{~mm}^{2} / \mathrm{HPF} \text { for a } \\
\text { total area of } 4.9 \mathrm{~mm}^{2}\end{array}$ \\
\hline $\begin{array}{l}\text { Landau et al., } 2014 \\
\text { (19) }\end{array}$ & $\begin{array}{l}\text { Semi-quantitative; } 5 \text { HPFs are evaluated for } \\
\text { presence of TB; A HPF is counted as positive for } \\
\text { TB when } 5 \text { or more tumor buds are present }\end{array}$ & $\begin{array}{l}\text { No budding (no budding } \\
\text { fields) } \\
\text { Focal budding (one to two } \\
\text { budding fields) } \\
\text { Extensive budding (three } \\
\text { or more budding fields) }\end{array}$ & $H \& E$ & Invasive front & $0.785 \mathrm{~mm}^{2} / \mathrm{HPF}$ \\
\hline
\end{tabular}

TB, tumor budding; HPF, high-power field; H\&E, hematoxylin and eosin; PanCK, pancytokeratin.

TB as a novel and promising tumor-related histomorphological prognostic factor in cancers of the esophagus and stomach.

\section{METHODS}

The focus of this work was to review the primary and secondary literature on TB in upper gastrointestinal carcinomas. Electronic keyword searches using Boolean operators were performed to identify relevant primary sources in the following databases: MEDLINE, MEDLINE In Process, Scopus, Web of Science, EMBASE, Google Scholar, and ISI Proceedings. Manual searches were performed of the reference lists. Searches were not limited by date and include all literature published up to the 1st of July, 2014. Case reports or notes were excluded. All identified studies were reviewed and assessed for relevance. Data from relevant publications were extracted and categorized according to tumor type and location. Data extraction tables were reviewed by all four authors of this manuscript.

\section{TUMOR BUDDING IN CARCINOMAS OF THE ESOPHAGUS AND STOMACH \\ ESOPHAGEAL CARCINOMA}

Carcinomas of the esophagus are the sixth most common malignancy worldwide in males and the fifth most common cause of death (15). Esophageal cancer occurs in two major histological types: SCC most frequently arises in the upper esophagus and accounts for up to $90 \%$ of esophageal carcinomas in developing countries (1). Esophageal adenocarcinoma, frequently originates from pre-malignant Barrett Mucosa ("Barrett's carcinoma"), occurs in the lower third of the esophagus and has rapidly increased in incidence in developed countries over the last decades (1). Advances in early detection and multimodality therapy have increased survival rates of patients with esophageal cancers making histopathological risk stratification an important tool for therapeutic decision making. This applies both to early cancers of the esophagus, which can be treated by endoscopic mucosal resection (EMR), radiofrequency ablation, or limited resection (Merendino's procedure) as well as advanced disease requiring neo-adjuvant chemotherapy and esophagectomy.

\section{Tumor budding as histomorphological prognostic factor in squamous cell carcinoma of the esophagus}

In SCC of the esophagus, TB has been evaluated for risk stratification in different clinical settings (Table 2). In an analysis of 56 patients with surgically resected esophageal SCC of stages IIII, high-grade TB was identified by Roh and colleagues in $60.7 \%$ of cases (11). Increased TB predicted more advanced pT-stage, lymphovascular invasion (LVI), perineural invasion, larger tumor size, and circumferential resection margin involvement. Further, patients with high-grade TB had a reduced 3-year survival outcome of $30.7 \%$ after esophagectomy in comparison to $72.3 \%$ in patients with low-grade budding. These findings are supported by two subsequent publications [Ref. (12), $n=136$; (14), $n=82$ ], which describe high-grade TB in $56.1-60.2 \%$ of patients undergoing esophagectomy for stage I-IV esophageal SCC $(12,14)$. Even though both authors included a significant subset of patients receiving pre-operative and/or adjuvant chemotherapy, both studies independently confirm TB as an indicator of poor survival outcome with 5-year survival rates of 35.0-35.4\% in patients with high-grade TB as compared to $81.3-86.9 \%$ in absence of this feature. Further, high-grade TB consistently predicted more advanced T-stage and lymph node metastasis $(12,14)$. Miyata and associates addressed TB in the neo-adjuvant setting using a cohort of 74 stage II-IV patients. Interestingly, TB was also found to be a useful prognostic indicator in patients who received neo-adjuvant chemotherapy followed by surgery for advanced esophageal SCC (13). In particular, the 5-year survival rate of patients with highgrade TB in the resection specimen was $17 \%$, compared with $49 \%$ for those with low-grade TB. Further, TB correlated significantly with a poor clinical chemotherapy response.

Moreover, TB was confirmed as a decisive prognostic indicator in surgically treated early-stage esophageal SCC in a recent study including 79 pT1 patients by Teramoto and colleagues (15). In these early-stage patients, only $36.7 \%$ showed high-grade TB while $63.3 \%$ were assigned to the low-grade budding group; this data suggest that TB may be less frequently encountered in patients with limited disease. Following esophagectomy, the investigators report 3 -year survival rates of $48.8 \%$ for $\mathrm{pT} 1$ patients with high-grade TB 
Table 2 | Studies on tumor budding as a histomorphological prognostic factor in squamous cell carcinoma of the esophagus

\begin{tabular}{|c|c|c|c|c|c|c|c|c|}
\hline Reference & $\begin{array}{l}\text { Tumor } \\
\text { subtype }\end{array}$ & Stage & $N$ & Treatment & $\begin{array}{l}\text { Method for } \\
\text { assessment } \\
\text { of TuB }\end{array}$ & $\begin{array}{l}\text { Low-grade/ } \\
\text { high-grade } \\
\text { TB\% }\end{array}$ & $\begin{array}{l}\text { Correlation of high-grade } \\
\text { TB with clinicopathological } \\
\text { features }(p<0.05)\end{array}$ & Outcome \\
\hline $\begin{array}{l}\text { Roh et al., } \\
2004 \text { (11) }\end{array}$ & $\mathrm{SCC}$ & $|-|||$ & 56 & $\begin{array}{l}56 / 56 \text { Patients were treated by } \\
\text { primary resection }\end{array}$ & $\begin{array}{l}\text { Ueno et al., } 2004 \\
\text { (22) H\&E }\end{array}$ & $39.3 / 60.7$ & $\begin{array}{l}\text { T-stage, L1, Pn1, larger tumor size, } \\
\text { circumferential resection margin } \\
\text { involvement, advanced AJCC-stage }\end{array}$ & $\begin{array}{l}\text { 3-year survival rates after esophagectomy } \\
\text { with low-grade TB: } 72.3 \% \text {; high-grade TB: } \\
30.7 \%(p=0.04)\end{array}$ \\
\hline $\begin{array}{l}\text { Koike et al., } \\
2008 \text { (12) }\end{array}$ & $\mathrm{SCC}$ & I-IV & 136 & $\begin{array}{l}\text { 82/136 Patients received } \\
\text { pre-operative CTX-and/or RTX } \\
\text { 52/139 Patients received adjuvant } \\
\text { CTX-and/or RTX }\end{array}$ & $\begin{array}{l}\text { Ueno et al., } 2004 \\
\text { (22) H\&E }\end{array}$ & $39.8 / 60.2$ & $\begin{array}{l}\text { T-stage, N-stage, L1, increased invasion } \\
\text { depth, larger tumor size, intramural } \\
\text { metastasis }\end{array}$ & $\begin{array}{l}\text { 5-year survival rates after esophagectomy } \\
\text { with low-grade TB: } 35.4 \% \text {; high-grade TB: } \\
81.3 \%(p=0.001)\end{array}$ \\
\hline $\begin{array}{l}\text { Miyata } \\
\text { et al., } 2009 \\
\text { (13) }\end{array}$ & $\mathrm{SCC}$ & II-IV & 74 & $\begin{array}{l}\text { 74/74 Patients received } \\
\text { pre-operative CTX }\end{array}$ & $\begin{array}{l}\text { Ueno et al., } 2004 \\
\text { (22) H\&E }\end{array}$ & $59 / 41$ & Not analyzed & $\begin{array}{l}\text { 5-year survival rates after esophagectomy } \\
\text { with low-grade TB: } 49 \% \text {; high-grade TB: } \\
17 \%(p<0.001)\end{array}$ \\
\hline $\begin{array}{l}\text { Nakanishi } \\
\text { et al., } 2011 \\
\text { (14) }\end{array}$ & $\mathrm{SCC}$ & I-IV & 82 & $\begin{array}{l}82 / 82 \text { Patients were treated by } \\
\text { primary resection } \\
\text { 22/82 Patients received adjuvant } \\
\text { CTX }\end{array}$ & $\begin{array}{l}\text { Ueno et al., } 2004 \\
\text { (22) PanCK }\end{array}$ & $43.9 / 56.1$ & $\begin{array}{l}\text { T-stage, N-stage, L1, V1, larger tumor } \\
\text { size }\end{array}$ & $\begin{array}{l}\text { Disease-free survival time in patients with } \\
\text { low-grade TB: } 113 \text { months; in patients with } \\
\text { high-grade TB: } 31 \text { months }(p<0.0001)\end{array}$ \\
\hline $\begin{array}{l}\text { Teramoto } \\
\text { et al., } 2013 \\
\text { (15) }\end{array}$ & $\mathrm{SCC}$ & I & 79 & $\begin{array}{l}\text { 73/79 Patients were treated by } \\
\text { primary resection } \\
6 / 79 \text { Patients were treated by EMR } \\
\text { followed by radical surgery } \\
11 / 79 \text { Patients received adjuvant } \\
\text { CTX- and/or RTX }\end{array}$ & $\begin{array}{l}\text { Modified Ueno } \\
\text { et al., } 2004(22) \\
\text { H\&E }\end{array}$ & $63.3 / 36.7$ & $\begin{array}{l}\mathrm{N} \text {-stage, } \mathrm{L} 1, \mathrm{~V} 1 \text {, tumor differentiation, } \\
\text { increased invasion depth }\end{array}$ & $\begin{array}{l}\text { 3-year survival rates after esophagectomy } \\
\text { with low-grade TB: } 94.5 \% \text {; High-grade TB: } \\
\text { 48.8\% ( } p<0.001)\end{array}$ \\
\hline
\end{tabular}

TB, tumor budding; SCC, squamous cell carcinoma; AC, adenocarcinoma; CTX, chemotherapy; RTX, radiotherapy; H\&E, hematoxylin and eosin; PanCK, pancytokeratin; V1, venous invasion; L1, Iymphatic invasion; Pn1, perineural invasion 
as compared to $94.5 \%$ in the absence of this feature. Within the cohort, 11 patients received adjuvant therapy.

In summary, these studies support the use of $\mathrm{TB}$ as a useful histomorphological prognostic factor for primarily resected esophageal SCC, in the neo-adjuvant setting and in early-stage cancers of the esophagus. The validation of TB as a histomorphological prognostic factor in squamous cell esophageal cancer in large multi-centric studies is therefore recommended.

\section{Tumor budding as histomorphological prognostic factor in adenocarcinoma of the esophagus}

Four studies were identified following a literature search examining $\mathrm{TB}$ in $\mathrm{AC}$ of the esophagus or gastro-esophageal junction (Barrett's carcinoma) (Table 3). In a well-designed, two-center retrospective study including 287 cases of stage I-IV esophageal AC and 69 cases of SCC by Brown and associates, high-grade TB was associated with a median overall survival outcome of 15 months while patients with low-grade TB reached 31 months (16). Importantly, TB retained prognostic significance in both the $\mathrm{AC}$ and SCC subgroup ( $p=0.0001$ and $p=0.021$, respectively), when including neo-adjuvant therapy $(n=115 / 356$ patients; $p=0.003$ ) and in multivariable analysis with age, $N$-stage, and overall-stage $(p=0.002)$. Further, high-grade TB was associated with higher overall TNM-stage and adverse clinicopathological features such as lymph node metastasis, poor tumor differentiation, and incomplete excision. However, no separate analysis of SCC and AC was attempted concerning TNM-relevant clinicopathological features. Of note, a recent study presented at the Annual Meeting of the German Society of Pathology confirmed the association of TB with aggressive histopathology of esophageal and GI-junction AC on an independent set of 86 stage I-IV patients treated by primary resection (17). In particular, high-grade TB correlated significantly with advanced T-stage, higher tumor grade, non-intestinal/diffuse histological subtype, and higher rates of R1-resection. Survival analysis showed a trend toward poor overall survival in patients with high-grade TB but did not reach statistical significance, possibly due to the relatively small number of patients under study.

Two independent studies specifically address the prognostic impact of $\mathrm{TB}$ in early-stage $\mathrm{AC}$ of the esophagus. In 42 patients with surgically treated pT1 AC, Nowak and colleagues demonstrate a significantly increased rate of tumor recurrence and nodal metastasis with high-grade TB (18). Further, high-grade TB predicted a high risk for adverse survival outcome $(\mathrm{HR}=3.06 ; p=0.015)$. These results were recently expanded in a well-designed retrospective analysis by Landau et al. for 210 surgically resected pT1 AC of the esophagus (19). The authors identify a significant correlation between TB-grade and submucosal invasion. In fact, 95\% of tumors with extensive TB invaded the superficial (pT1a) or deep submucosal layer (pT1b) as compared to $54 \%$ of cases with none or focal TB $(p<0.001)$. Further, extensive TB correlated strongly with aggressive histopathological features, including poor tumor differentiation, angioinvasion, and larger tumor size (all $p<0.001)$. Even though the overall outcome is favorable in $\mathrm{pT} 1$ patients, Landau and colleagues report a survival rate of only $37 \%$ of patients with extensive TB at 5 years follow-up as compared to $79 \%$ in absence of this feature $(p<0.0001)$. In multivariable analysis, the negative prognostic impact of TB (HR 3.3; 95\% CI: $1.5-7.4 ; p=0.004$ ) was found to be independent of submucosal invasion depth, N-stage, patient age, and type of surgery. Similar results were observed for tumor recurrence at 24 months after surgery; while only $5 \%$ of patients without TB relapsed, tumor recurrence was found in $19 \%$ of those with focal TB and $36 \%$ of patients with extensive TB $(p<0.0001)$. This was independent of both $\mathrm{T}$ - and $\mathrm{N}$-stage in multivariable analysis $(\mathrm{HR}=3.2 ; 95 \%$ $\mathrm{CI}=1.4-7.0)$.

Taken together, these studies indicate that TB may be a valuable predictor of aggressiveness of disease in esophageal AC. Early esophageal carcinoma with lamina propria (pT1a) or submucosal invasion ( $\mathrm{pT} 1 \mathrm{~b})$ not infrequently take a detrimental course as a consequence of micrometastasis already present at the time of resection (54). EMR is an increasingly popular treatment option for the early-stage subgroup. Precise risk assessment in the surgical pathology practice is therefore of crucial importance for clinical management of early-stage AC. In locally advanced AC of the esophagus, TB in the resection specimen may serve as a valuable prognostic indicator to guide clinical follow-up. Large, multi-centric studies including robust statistical analysis are therefore recommended to validate the prognostic impact of TB in the clinical management of esophageal AC.

\section{Future outlook}

Opportunities for further study of TB seem abundant in esophageal cancer, as several important factors are unique to the assessment of histomorphological biomarkers - and particularly $\mathrm{TB}$ - in this disease. First, SCC is common in the esophagus but very rare in other locations of the GI-tract. As TB was initially defined as a histomorphological prognostic factor in the microenvironment of $\mathrm{AC}$ of the colon and rectum, the need of a systematic comparison of the biological characteristics of tumor buds in SCC of the esophagus and AC of the GI-tract is evident. A conserved pattern of features related to the process of EMT would further support the notion of tumor buds as histomorphological hallmark of aggressive disease biology in the tumor microenvironment.

Second, multimodality treatment strategies for esophageal cancers differ from cancers of the stomach and colorectum. While presence of TB in the surgically resected specimen of CRC may be an indicator of aggressive disease requiring adjuvant chemotherapy, esophageal cancers are commonly treated in the neo-adjuvant setting where no information on budding activity in the tumor microenvironment based on a resection specimen will be available. Consequently, novel predictive factors based on biopsy material of esophageal cancers are needed that could aid risk stratification in conjunction with imaging and clinical findings. Interestingly, intra-tumoral budding (ITB) may represent a novel prognostic feature present in pre-operative biopsies of cancers of the GI-tract, particularly of the colorectum $(41,55,56)$. Based on the consistent association of $\mathrm{TB}$ with aggressive histomorphological features in both AC and SCC, investigation of ITB in esophageal carcinomas may be expected to provide similar information.

Third, no agreement on the optimal approach to assess TB in esophageal cancer has been found. For the visualization of TB, two studies using cytokeratin staining were identified $(14,17)$, while the remaining studies are based on standard H\&E staining (11-13, 
Table 3 | Studies on tumor budding as a histomorphological prognostic factor in adenocarcinoma of the esophagus.

\begin{tabular}{|c|c|c|c|c|c|c|c|c|}
\hline Reference & $\begin{array}{l}\text { Tumor } \\
\text { subtype }\end{array}$ & Stage & $N$ & Treatment & $\begin{array}{l}\text { Method for } \\
\text { assessment } \\
\text { of TuB }\end{array}$ & $\begin{array}{l}\text { Low-grade/ } \\
\text { high-grade } \\
\text { TB\% }\end{array}$ & $\begin{array}{l}\text { Correlation of high-grade } \\
\text { TB with clinicopathological } \\
\text { features }(p<0.05)\end{array}$ & Outcome \\
\hline $\begin{array}{l}\text { Brown } \\
\text { et al., } 2010 \\
(16)\end{array}$ & $\mathrm{AC} / \mathrm{SCC}$ & I-IV & $\begin{array}{l}\text { Total: } 356 \\
69 \text { SCC } \\
287 \text { AC }\end{array}$ & $\begin{array}{l}\text { 241/356 Patients treated } \\
\text { by primary resection } \\
\text { 115/356 Patients received } \\
\text { pre-operative CTX }\end{array}$ & $\begin{array}{l}\text { Ueno et al., } \\
2004 \text { (22) H\&E }\end{array}$ & $48.3 / 51.7$ & $\begin{array}{l}\text { T-stage, N-stage, poor tumor } \\
\text { differentiation, circumferential } \\
\text { resection margin involvement, } \\
\text { higher overall TNM-stage, low } \\
\text { inflammatory response. No } \\
\text { separate analysis of SCC and AC } \\
\text { was performed. }\end{array}$ & $\begin{array}{l}\text { Low-grade TB: OS } 31 \text { months; } \\
\text { high-grade TB: OS } 15 \text { months } \\
\text { ( } p<0.0001) \\
\text { Prognostic impact of TB is } \\
\text { independent of histologic type } \\
\text { (SCC, } p=0.021 ; A C, p=0.0001) \text {, } \\
\text { age, N-stage, overall stage }\end{array}$ \\
\hline $\begin{array}{l}\text { Thies et al., } \\
2013 \text { (17) }\end{array}$ & $A C$ & I-IV & 86 & $\begin{array}{l}86 / 86 \text { Patients were } \\
\text { treated by primary } \\
\text { resection }\end{array}$ & $\begin{array}{l}\text { Karamitopoulou } \\
\text { et al., } 2013 \\
\text { (25) PanCK }\end{array}$ & $60.5 / 39.5$ & $\begin{array}{l}\text { pT-stage, higher tumor grade, } \\
\text { non-intestinal/diffuse histological } \\
\text { subtype, higher rates of } \\
\text { R1-resection }\end{array}$ & $\begin{array}{l}\text { Survival analysis showed a trend to } \\
\text { worse survival for high-grade TB } \\
(p=0.15 \text {; ITB } p=0.13 \text { ) }\end{array}$ \\
\hline $\begin{array}{l}\text { Nowak } \\
\text { et al., } 2013 \\
\text { (18) }\end{array}$ & $A C$ & I & 42 & $\begin{array}{l}42 / 42 \text { Patients were } \\
\text { treated by primary } \\
\text { resection }\end{array}$ & $\begin{array}{l}\text { Adapted Ueno } \\
\text { et al., } 2004 \\
\text { (22) H\&E }\end{array}$ & Not specified & $\mathrm{N}$-stage & $\begin{array}{l}\text { High-grade TB was a strong } \\
\text { predictor of tumor recurrence } \\
(H R=14.21 ; p=0.022) \text { and } \\
\text { reduced } O S(H R=3.06 ; p=0.015)\end{array}$ \\
\hline $\begin{array}{l}\text { Landau } \\
\text { et al., } 2014 \\
\text { (19) }\end{array}$ & $A C$ & $\begin{array}{l}\text { I esophageal } \\
\text { AC or AC of } \\
\text { gastro } \\
\text { esophageal } \\
\text { junction }\end{array}$ & 210 & $\begin{array}{l}210 / 210 \text { Patients were } \\
\text { treated by primary } \\
\text { resection }\end{array}$ & $\begin{array}{l}\text { Ueno et al., } \\
2004 \text { (22) H\&E } \\
\text { adapted } \\
\text { according to } \\
\text { Ohike et al., } \\
2010 \text { (52) }\end{array}$ & $\begin{array}{l}\text { Any TB: } 44.3 \% \\
\text { focal: } 16 \% \\
\text { extensive } 28 \% \text { no } \\
\text { TB: } 55.7 \%\end{array}$ & $\begin{array}{l}\mathrm{N} \text {-stage, submucosal invasion } \\
\text { depth, grade, angioinvasion, } \\
\text { tumor size }\end{array}$ & $\begin{array}{l}\text { 5-year OS: no TB: } 79 \% \text {, focal TB: } \\
71 \% \text {, extensive TB: } 37 \%(p>0.001) \\
\text { Multivariate analysis: HR for death } \\
\text { (extensive TB): } 3.3(95 \% \\
\mathrm{Cl}=1.5-7.4, p=0.004) ; \\
\text { independent of T- and N-stage, age, } \\
\text { type of surgery } \\
\text { Disease recurrence at } 24 \text { months: } \\
\text { no TB: } 5 \% \text {, focal TB: } 19 \% \text {, extensive } \\
\text { TB: } 36 \% \\
\text { Multivariate analysis: HR for } \\
\text { recurrence (extensive TB): } 3.3 \text { (95\% } \\
\text { Cl=1.4-7.0, } p=0.005) ; \\
\text { independent of T- and } \mathrm{N} \text {-stage }\end{array}$ \\
\hline
\end{tabular}

TB, tumor budding; SCC, squamous cell carcinoma; AC, adenocarcinoma; CTX, chemotherapy; RTX, radiotherapy; H\&E, hematoxylin and eosin; PanCK, pancytokeratin; V1, venous invasion; L1, Iymphatic invasion;

Pn1, perineural invasion; OS, overall survival. 
15, 16, 18, 19). Methodologically, TB in esophageal SCC has been assessed in one densest high-power field (HPF, 200×) according to Ueno (22) by eight authors with variable modifications. Other authors have used the scoring approach suggested by Ohike (52) and the 10 HPF methods (25) (Tables 2 and 3). Only one study was identified assessing inter-observer variability for TB using a 10 HPF approach (17). Consequently, a systematic inter-observer study comparing different methods for the assessment of TB seems desirable both in SCC and AC to reach consensus on the optimal approach for daily diagnostic practice.

\section{GASTRIC ADENOCARCINOMA}

Gastric cancer is among the five most frequent cancers in males and females worldwide with an estimated 738,000 deaths in 2011 (15). Gastric AC occurs in two major histological subtypes according to the Lauren classification, intestinal, and diffuse (1). As standard of care, operable patients with stage II-III disease are treated with multimodality therapy following resection (57-59). For stage IB patients with node positive (T1 N1) and muscle invasive disease (T2 N0) the role of adjuvant chemotherapy is less clear. Even though the prognosis of early-stage patients is relatively favorable following complete resection of the primary tumor, individual patients may follow an aggressive clinical course characterized by local and distant disease recurrence (60). Additional prognostic factors such as TB may be particularly helpful for risk stratification in this setting to identify patients that may profit from multimodal treatment following resection.

Tumor budding as an adverse histomorphological prognostic factor in gastric adenocarcinoma

Literature analysis of TB in gastric AC identified only two studies from independent centers (Table 4). In 1992, Gabbert and colleagues analyzed the prognostic significance of tumor cell dissociation (TCD) at the invasive front of gastric AC in a cohort of 445 surgically treated stage I-IV patients (20). Even though TCD is not termed TB by the authors, the quantitative assessment of this feature is clearly very closely related to $\mathrm{TB}$ as described by Hase and colleagues (46) with TCD grades $0 / 1$ corresponding to absent/mild TB and TCD grade $2 / 3$ to moderate/severe TB. TCD grade $2 / 3$ was found in $51.7 \%$ of patients. Interestingly, the degree of TCD at the invasive front predicted aggressive disease with 5 -year survival of $38.5 \%$ in comparison to $92.3 \%$ in patients with absence of this feature, independently of T-stage, tumor size, and grade $(p=0.026)$. Further, patients with high-grade TCD frequently presented with more advanced T-stage, $\mathrm{N}$-stage, vascular invasion, high-grade tumors, and larger tumor size.

In a recently published study, Tanaka et al. address TB in a well characterized retrospective cohort of 320 surgically treated stage IIV gastric AC patients including 161 patients receiving adjuvant or palliative chemotherapy following resection (21). High-grade TB was observed in $60.0 \%$ of cases, a similar frequency as reported by Gabbert (20). Importantly, high-grade TB correlated significantly with TNM-relevant features including T-stage, $\mathrm{N}$-stage, lymphatic invasion as well as synchronous liver metastasis and distant metastasis. Further, high-grade TB was associated with larger tumor size and depressive macroscopic morphology. In patients with predominantly differentiated histology $(n=153)$, TB was found to

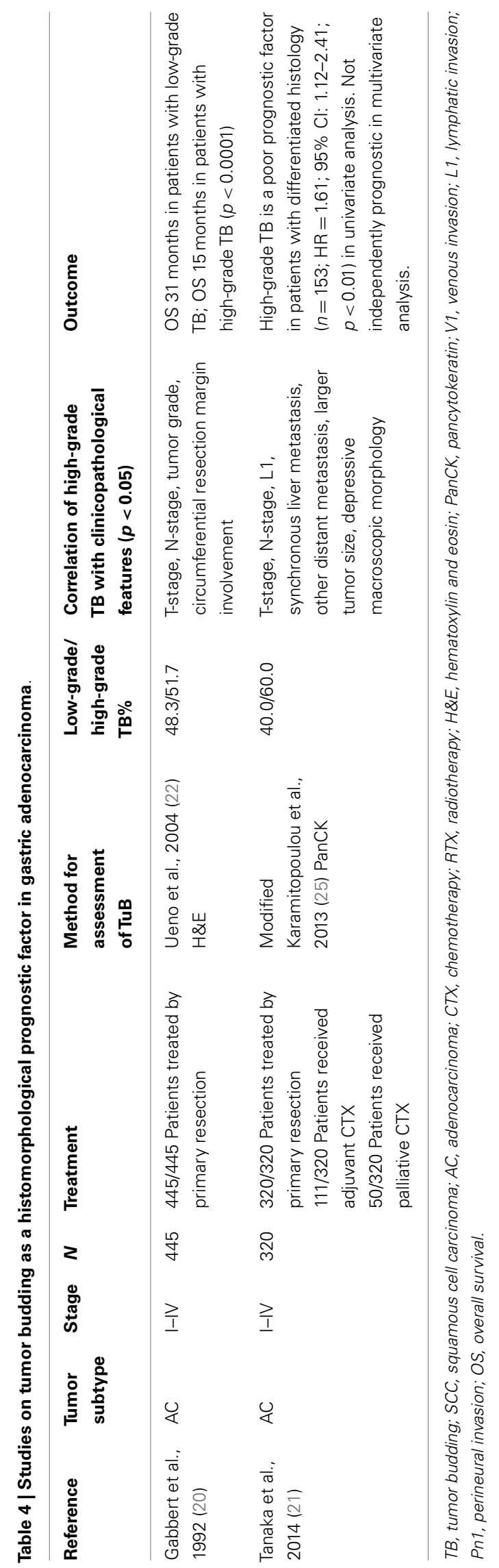

August 2014 | Volume 4 | Article 216 | 8 
be an adverse prognostic indicator $(\mathrm{HR}=1.61$; 95\% CI: $1.12-$ $2.41 ; p<0.01)$ in univariate analysis. However, when including other TNM-relevant features, TB did not retain prognostic significance in multivariate analysis. Taken together, TB may be a possibly highly prognostic feature that is clearly underrepresented in studies of histomorphological features of gastric cancer.

Tanaka and colleagues also provide insight into the biological processes that may contribute to the formation of tumor buds in gastric AC. Using immunohistochemistry, geographic protein expression analysis of the pro-proliferative and pro-invasive tropomyosin-related receptor kinase B (TrkB) in gastric carcinomas was performed. TrkB expression may promote EMT in malignant cells and has been associated with chemotherapy resistance of esophageal carcinomas $(61,62)$. In consistence with this, Tanaka and colleagues report an increased frequency of TB in patients with high TrkB expression at the tumor center, margin, or invasive front. Tumor buds themselves frequently over-expressed TrkB, confirming previous studies on this protein in tumor buds of colorectal cancer (39). Consequently, over-expression of TrkB expression may be a common feature of cells undergoing EMT and may allow increased resistance to pro-apoptotic stimuli and chemotherapeutic agents.

\section{Future outlook}

Data on the prognostic impact of TB in gastric AC is still sparse. More data are needed to reliably judge the potential value of TB for the clinical management and follow-up of gastric cancer patients. Further, the impact of TB in the early-stage subgroup, in preoperative biopsy specimens and in the adjuvant setting has yet to be addressed. To researchers interested in TB, gastric cancers also pose a challenge due to the higher frequency of poorly differentiated and signet cell carcinomas with a primary dissociative growth pattern. It has so far not been explicitly addressed whether gastric carcinomas or any other cancer of the GI-tract with a primary dissociative growth pattern should be defined as "high-grade TB" (Figure 3A). As signet cell carcinomas of the stomach also frequently display primary E-cadherin mutations, the use of this feature to characterize cells undergoing EMT is limited (63). We believe that differentiation of cancers with a primary dissociative growth pattern from cancers with high-grade TB should therefore be addressed on the base of morphology; the definition of TB as the presence of single cells and small clusters of up to five dedifferentiated tumor cells ahead of the invasive front implicates that a solid tumor body must be present for bona fide TB to occur (64) (Figure 3B). Clearly, the specific characteristics of TB in AC of different histological type and differentiation require further investigation.

\section{CONCLUSION}

Tumor budding is frequently observed in carcinomas of the upper gastrointestinal tract. It is a valuable tumor-related prognostic factor and indicator of aggressive disease biology. In esophageal and gastric carcinomas, presence of $\mathrm{TB}$ in the resection specimen predicts unfavorable clinicopathological features and early disease recurrence. Information on TB provided by the histopathologist could be of particular value for personalized patient management in two distinct clinical scenarios: first, information on TB could be an important factor for risk stratification of patients with locally invasive SCC or AC of the esophagus $(15,19)$. Consequently, patients with high-grade TB may benefit from esophagectomy
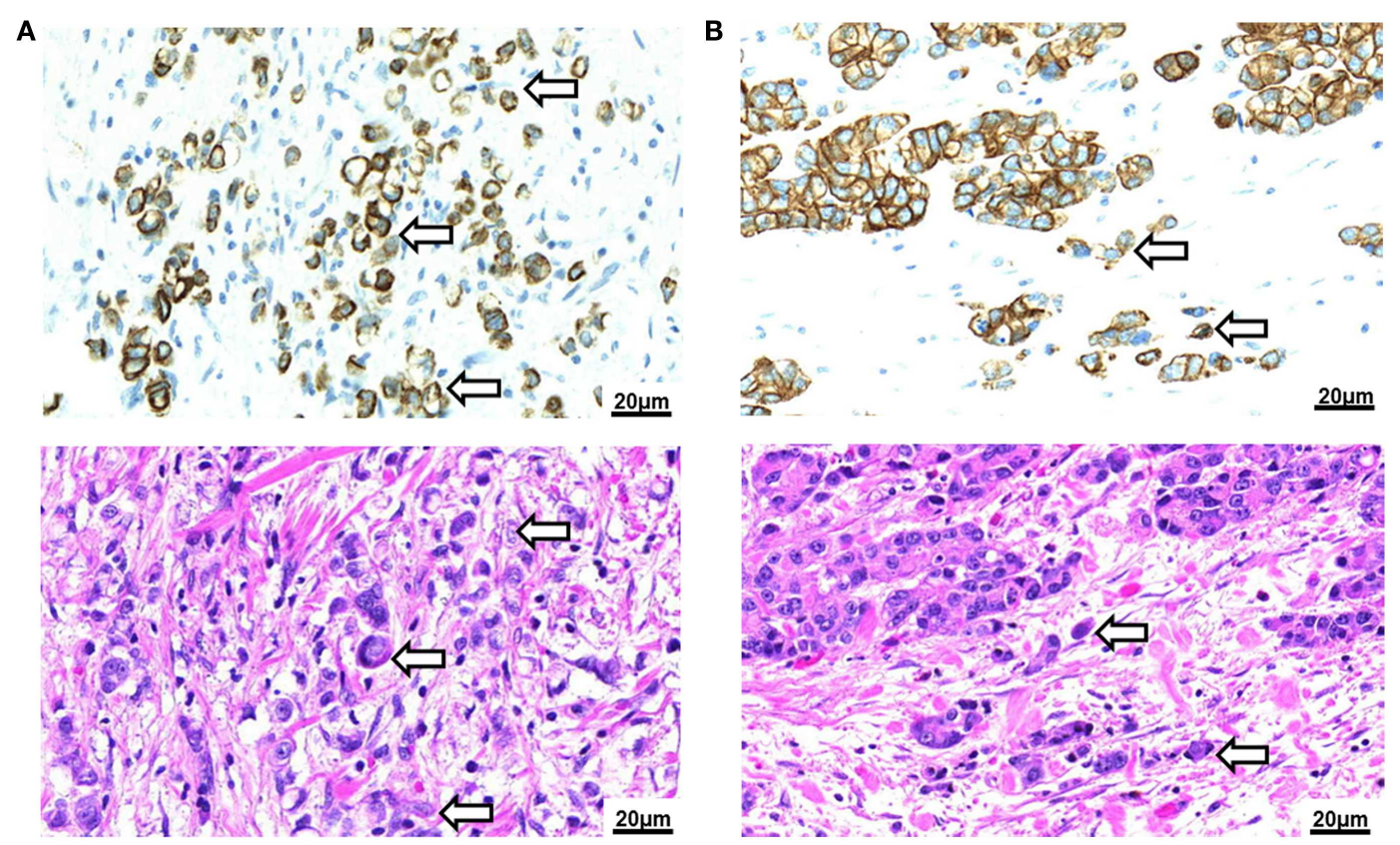

FIGURE 3 | Tumor budding in Barrett's carcinoma. (A) Poorly differentiated adenocarcinoma of the esophagus with signet cell component as seen in a pancytokeratin (top) and H\&E (bottom) stain $(250 \times)$. Tumor buds cannot be differentiated by morphology from the diffusely infiltrating tumor mass. (B) Intestinal type adenocarcinoma of the esophagus with presence of tumor buds at the invasive front as seen in a pancytokeratin (top) and H\&E (bottom) stain $(250 \times)$. 
rather than treatment with locally ablative procedures. It is fair to assume that assessment of TB in EMR specimens or preoperative biopsy material could provide important information on the relative risk for lymph node metastasis and disease recurrence. Further studies are therefore of particular importance to address this clinical scenario. Second, TB may be a valuable additional prognostic indicator to aid the selection of high risk patients with esophageal cancer for multimodality therapy. In particular, some patients with pT2 esophageal cancer present with early disease recurrence following resection of the primary tumor. In this setting, TB may provide additional prognostic information for personalized therapeutic approaches. However, a central limitation to these applications for TB in the assessment of esophageal and gastric cancers is still the relative scarcity of data. As compared to colorectal cancer where TB is already officially recognized as additional prognostic factor by the UICC (1), studies on TB in upper gastrointestinal cancers are based on a limited patient number and a small group of study centers. Large multi-centric studies including robust statistical analysis are therefore urgently needed to determine whether TB can assume a similar role in upper gastrointestinal cancers.

Standardization of assessment methods is another central roadblock for the establishment of TB as histomorphological prognostic factor in gastrointestinal pathology. This holds true for carcinomas of the esophagus and stomach and also the colorectum. In analogy to the BRE-score for breast cancer or the Gleason score in prostate cancer, TB shows potential to assume an important role for prognostication and therapy planning in GI-cancers. Consequently, approaches for standardization should not be limited to one section of the GI-tract but the attempt to find consensus should be made on an integrative basis. This requires agreement on both qualitative and quantitative criteria.

For qualitative criteria, broad consent exists on the definition of TB as single tumor cells or small clusters of up to five cells ahead of the invasive front (65). The most widely used approach to visualize this feature is a standard H\&E stain, but expert opinion is variable $(19,27,66)$. In cases where strong inflammation is present at the invasive front, differentiation of tumor buds from macrophages, cell detritus, ruptured glands, and reactive stromal cells can be challenging. Pancytokeratin immunohistochemistry has been recommended to better identify tumor buds in difficult cases and may allow quantification of TB using digital imaging $(66,67)$. For quantitative criteria, consensus on a reproducible approach to define low or high-grade TB seems mandatory. A large number of different methods have been suggested for the assessment of TB in daily diagnostic practice, but systematic inter-observer studies are few. To provide evidence on the optimal methodological approach to visualize $\mathrm{TB}$, a systematic comparison of the interobserver reproducibility in large multi-centric studies is therefore recommended.

\section{REFERENCES}

1. Bosman FT, World Health Organization, and International Agency for Research on Cancer. WHO Classification of Tumours of the Digestive System. Lyon: International Agency for Research on Cancer (2010).

2. Stahl M, Budach W, Meyer HJ, Cervantes A; E.G.W. Group. Esophageal cancer: clinical practice guidelines for diagnosis, treatment and follow-up. Ann Oncol (2010) 21(Suppl 5):v46-9. doi:10.1093/annonc/mdq163
3. Rice TW, Blackstone EH, Rusch VW. 7th edition of the AJCC Cancer Staging Manual: esophagus and esophagogastric junction. Ann Surg Oncol (2010) 17:1721-4. doi:10.1245/s10434-010-1024-1

4. Raja S, Rice TW, Goldblum JR, Rybicki LA, Murthy SC, Mason DP, et al. Esophageal submucosa: the watershed for esophageal cancer. J Thorac Cardiovasc Surg (2011) 142:1403.e-11.e. doi:10.1016/j.jtcvs.2011.09.027

5. Barbour AP, Jones M, Brown I, Gotley DC, Martin I, Thomas J, et al. Risk stratification for early esophageal adenocarcinoma: analysis of lymphatic spread and prognostic factors. Ann Surg Oncol (2010) 17:2494-502. doi:10.1245/s10434010-1025-0

6. Zlobec I, Lugli A. Epithelial mesenchymal transition and tumor budding in aggressive colorectal cancer: tumor budding as oncotarget. Oncotarget (2010) 1:651-61.

7. De Craene B, Berx G. Regulatory networks defining EMT during cancer initiation and progression. Nat Rev Cancer (2013) 13:97-110. doi:10.1038/ $\operatorname{nrc} 3447$

8. Kevans D, Wang LM, Sheahan K, Hyland J, O'Donoghue D, Mulcahy H, et al. Epithelial-mesenchymal transition (EMT) protein expression in a cohort of stage II colorectal cancer patients with characterized tumor budding and mismatch repair protein status. Int J Surg Pathol (2011) 19:751-60. doi:10.1177/ 1066896911414566

9. Lugli A, Iezzi G, Hostettler I, Muraro MG, Mele V, Tornillo L, et al. Prognostic impact of the expression of putative cancer stem cell markers CD133 CD166, CD44s, EpCAM, and ALDH1 in colorectal cancer. Br J Cancer (2010) 103:382-90. doi:10.1038/sj.bjc.6605762

10. Prall F. Tumour budding in colorectal carcinoma. Histopathology (2007) 50:151-62. doi:10.1111/j.1365-2559.2006.02551.x

11. Roh MS, Lee JI, Choi PJ. Tumor budding as a useful prognostic marker in esophageal squamous cell carcinoma. Dis Esophagus (2004) 17:333-7. doi:10. 1111/j.1442-2050.2004.00436.x

12. Koike M, Kodera Y, Itoh Y, Nakayama G, Fujiwara M, Hamajima N, et al. Multivariate analysis of the pathologic features of esophageal squamous cell cancer: tumor budding is a significant independent prognostic factor. Ann Surg Oncol (2008) 15:1977-82. doi:10.1245/s10434-008-9901-6

13. Miyata H, Yoshioka A, Yamasaki M, Nushijima Y, Takiguchi S, Fujiwara $\mathrm{Y}$, et al. Tumor budding in tumor invasive front predicts prognosis and survival of patients with esophageal squamous cell carcinomas receiving neoadjuvant chemotherapy. Cancer (2009) 115:3324-34. doi:10.1002/cncr. 24390

14. Nakanishi Y, Ohara M, Doumen H, Kimura N, Ishidate T, Kondo S. Correlation between tumor budding and post-resection prognosis in patients with invasive squamous cell carcinoma of the thoracic esophagus. World J Surg (2011) 35:349-56. doi:10.1007/s00268-010-0880-y

15. Teramoto H, Koike M, Tanaka C, Yamada S, Nakayama G, Fujii T, et al. Tumor budding as a useful prognostic marker in T1-stage squamous cell carcinoma of the esophagus. J Surg Oncol (2013) 108:42-6. doi:10.1002/jso.23341

16. Brown M, Sillah K, Griffiths EA, Swindell R, West CM, Page RD, et al. Tumour budding and a low host inflammatory response are associated with a poor prognosis in oesophageal and gastro-oesophageal junction cancers. Histopathology (2010) 56:893-9. doi:10.1111/j.1365-2559.2010.03559.x

17. Thies S, Slotta-Huspenina J, Zlobec I. The impact of tumor budding in oesophageal adenocarcinomas. Pathologe (2013) 34:78. doi:10.1016/j.ejca.2012. 10.022

18. Nowak JA, Agoston A, Zheng Y, Bueno R, Odze RD, Srivastava A. Tumor budding is a predictor of nodal metastasis and tumor recurrence in T1 esophageal adenocarcinoma. Mod Pathol (2013) 26:169A.

19. Landau MS, Hastings SM, Foxwell TJ, Luketich JD, Nason KS, Davison JM. Tumor budding is associated with an increased risk of lymph node metastasis and poor prognosis in superficial esophageal adenocarcinoma. Mod Pathol (2014). doi:10.1038/modpathol.2014.66

20. Gabbert HE, Meier S, Gerharz CD, Hommel G. Tumor-cell dissociation at the invasion front: a new prognostic parameter in gastric cancer patients. Int J Cancer (1992) 50:202-7. doi:10.1002/ijc.2910500208

21. Tanaka K, Shimura T, Kitajima T, Kondo S, Ide S, Okugawa Y, et al. Tropomyosinrelated receptor kinase $\mathrm{B}$ at the invasive front and tumour cell dedifferentiation in gastric cancer. Br J Cancer (2014) 110:2923-34. doi:10.1038/bjc.2014.228

22. Ueno H, Mochizuki H, Hashiguchi Y, Shimazaki H, Aida S, Hase K, et al. Risk factors for an adverse outcome in early invasive colorectal carcinoma. Gastroenterology (2004) 127:385-94. doi:10.1053/j.gastro.2004.04.022 
23. Nakamura T, Mitomi H, Kanazawa H, Ohkura Y, Watanabe M. Tumor budding as an index to identify high-risk patients with stage II colon cancer. Dis Colon Rectum (2008) 51:568-72. doi:10.1007/s10350-008-9192-9

24. Wang LM, Kevans D, Mulcahy H, O’Sullivan J, Fennelly D, Hyland J, et al. Tumor budding is a strong and reproducible prognostic marker in T3N0 colorectal cancer. Am J Surg Pathol (2009) 33:134-41. doi:10.1097/PAS.0b013e318184cd55

25. Karamitopoulou E, Zlobec I, Kolzer V, Kondi-Pafiti A, Patsouris ES, Gennatas K, et al. Proposal for a 10-high-power-fields scoring method for the assessment of tumor budding in colorectal cancer. Mod Pathol (2013) 26:295-301. doi:10.1038/modpathol.2012.155

26. Masaki T, Matsuoka H, Sugiyama M, Abe N, Sakamoto A, Watanabe T, et al. Tumor budding and evidence-based treatment of T2 rectal carcinomas. J Surg Oncol (2005) 92:59-63. doi:10.1002/jso.20369

27. Mitrovic B, Schaeffer DF, Riddell RH, Kirsch R. Tumor budding in colorectal carcinoma: time to take notice. Mod Pathol (2012) 25:1315-25. doi:10.1038/ modpathol.2012.94

28. Ueno H, Mochizuki H, Shinto E, Hashiguchi Y, Hase K, Talbot IC. Histologic indices in biopsy specimens for estimating the probability of extended local spread in patients with rectal carcinoma. Cancer (2002) 94:2882-91. doi: $10.1002 /$ cncr.10551

29. Okuyama T, Oya M, Ishikawa H. Budding as a useful prognostic marker in pT3 well- or moderately-differentiated rectal adenocarcinoma. J Surg Oncol (2003) 83:42-7. doi:10.1002/jso.10230

30. Vieth M, Quirke P, Lambert R, von Karsa L, Risio M; International Agency for Research on Cancer. European guidelines for quality assurance in colorectal cancer screening and diagnosis. First Edition - Annotations of colorectal lesions. Endoscopy (2012) 44(Suppl 3):SE131-9. doi:10.1055/s-0032-1309798

31. Watanabe T, Itabashi M, Shimada Y, Tanaka S, Ito Y, Ajioka Y, et al. Japanese Society for Cancer of the, and Rectum, Japanese Society for Cancer of the Colon and Rectum (JSCCR) guidelines 2010 for the treatment of colorectal cancer. Int J Clin Oncol (2012) 17:1-29. doi:10.1007/s10147-011-0315-2

32. Schmoll HJ, Van Cutsem E, Stein A, Valentini V, Glimelius B, Haustermans K, et al. ESMO Consensus Guidelines for management of patients with colon and rectal cancer. A personalized approach to clinical decision making. Ann Oncol (2012) 23:2479-516. doi:10.1093/annonc/mds236

33. van de Velde CJ, Boelens PG, Borras JM, Coebergh JW, Cervantes A, Blomqvist L, et al. EURECCA colorectal: multidisciplinary management: European consensus conference colon \& rectum. Eur J Cancer (2014) 50:e1-1. doi:10.1016/j. ejca.2013.06.048

34. Jass JR, Barker M, Fraser L, Walsh MD, Whitehall VL, Gabrielli B, et al. APC mutation and tumour budding in colorectal cancer. J Clin Pathol (2003) 56:69-73. doi:10.1136/jcp.56.1.69

35. Guzinska-Ustymowicz K. MMP-9 and cathepsin B expression in tumor budding as an indicator of a more aggressive phenotype of colorectal cancer (CRC). Anticancer Res (2006) 26:1589-94.

36. Pyke C, Salo S, Ralfkiaer E, Romer J, Dano K, Tryggvason K. Laminin-5 is a marker of invading cancer cells in some human carcinomas and is coexpressed with the receptor for urokinase plasminogen activator in budding cancer cells in colon adenocarcinomas. Cancer Res (1995) 55:4132-9.

37. Koelzer VH, Karamitopoulou E, Dawson H, Kondi-Pafiti A, Zlobec I, Lugli A. Geographic analysis of RKIP expression and its clinical relevance in colorectal cancer. Br J Cancer (2013) 108:2088-96. doi:10.1038/bjc.2013.197

38. Dawson H, Koelzer VH, Karamitopoulou E, Economou M, Hammer C, Muller $\mathrm{DE}$, et al. The apoptotic and proliferation rate of tumour budding cells in colorectal cancer outlines a heterogeneous population of cells with various impacts on clinical outcome. Histopathology (2014) 64:577-84. doi:10.1111/his.12294

39. Dawson HAE, Zlobec I, Koelzer VH, Karamitopoulou E, Lugli A. Expression pattern of TrkB in colorectal cancer supports anoikis-resistance as a survival mechanism for tumor budding cells. Virchows Arch (2013) 463: S107.

40. Jung A, Schrauder M, Oswald U, Knoll C, Sellberg P, Palmqvist R, et al. The invasion front of human colorectal adenocarcinomas shows co-localization of nuclear beta-catenin, cyclin D1, and p16INK4A and is a region of low proliferation. Am J Pathol (2001) 159:1613-7. doi:10.1016/S0002-9440(10)63007-6

41. Rogers AC, Gibbons D, Hanly AM, Hyland JM, O'Connell PR, Winter DC, et al. Prognostic significance of tumor budding in rectal cancer biopsies before neoadjuvant therapy. Mod Pathol (2014) 27:156-62. doi:10.1038/modpathol. 2013.124

42. Tallerico R, Todaro M, Di Franco S, Maccalli C, Garofalo C, Sottile R, et al. Human NK cells selective targeting of colon cancer-initiating cells: a role for natural cytotoxicity receptors and MHC class I molecules. J Immunol (2013) 190:2381-90. doi:10.4049/jimmunol.1201542

43. Zlobec I, Minoo P, Terracciano L, Baker K, Lugli A. Characterization of the immunological microenvironment of tumour buds and its impact on prognosis in mismatch repair-proficient and -deficient colorectal cancers. Histopathology (2011) 59:482-95. doi:10.1111/j.1365-2559.2011.03975.x

44. Hostettler L, Zlobec I, Terracciano L, Lugli A. ABCG5-positivity in tumor buds is an indicator of poor prognosis in node-negative colorectal cancer patients. World J Gastroenterol (2010) 16:732-9. doi:10.3748/wjg.v16.i6.732

45. Morodomi T, Isomoto H, Shirouzu K, Kakegawa K, Irie K, Morimatsu M. An index for estimating the probability of lymph node metastasis in rectal cancers. Lymph node metastasis and the histopathology of actively invasive regions of cancer. Cancer (1989) 63:539-43. doi:10.1002/1097-0142(19890201)63:3<539: :AID-CNCR2820630323>3.0.CO;2-S

46. Hase K, Shatney C, Johnson D, Trollope M, Vierra M. Prognostic value of tumor "budding" in patients with colorectal cancer. Dis Colon Rectum (1993) 36:627-35. doi:10.1007/BF02238588

47. Nakamura T, Mitomi H, Kikuchi S, Ohtani Y, Sato K. Evaluation of the usefulness of tumor budding on the prediction of metastasis to the lung and liver after curative excision of colorectal cancer. Hepatogastroenterology (2005) 52:1432-5.

48. Ueno H, Murphy J, Jass JR, Mochizuki H, Talbot IC. Tumour 'budding' as an index to estimate the potential of aggressiveness in rectal cancer. Histopathology (2002) 40:127-32. doi:10.1046/j.1365-2559.2002.01324.x

49. Ono M, Sakamoto M, Ino Y, Moriya Y, Sugihara K, Muto T, et al. Cancer cell morphology at the invasive front and expression of cell adhesionrelated carbohydrate in the primary lesion of patients with colorectal carcinoma with liver metastasis. Cancer (1996) 78:1179-86. doi:10.1002/(SICI)10970142(19960915)78:6<1179::AID-CNCR3>3.0.CO;2-5

50. Park KJ, Choi HJ, Roh MS, Kwon HC, Kim C. Intensity of tumor budding and its prognostic implications in invasive colon carcinoma. Dis Colon Rectum (2005) 48:1597-602. doi:10.1007/s10350-005-0060-6

51. Lugli A, Karamitopoulou E, Panayiotides I, Karakitsos P, Rallis G, Peros G, et al. CD8+ lymphocytes/tumour-budding index: an independent prognostic factor representing a 'pro-/anti-tumour' approach to tumour host interaction in colorectal cancer. Br J Cancer (2009) 101:1382-92. doi:10.1038/ sj.bjc. 6605318

52. Ohike N, Coban I, Kim GE, Basturk O, Tajiri T, Krasinskas A, et al. Tumor budding as a strong prognostic indicator in invasive ampullary adenocarcinomas. Am J Surg Pathol (2010) 34:1417-24. doi:10.1097/PAS.0b013e3181f0b05a

53. Horcic M, Koelzer VH, Karamitopoulou E, Terracciano L, Puppa G, Zlobec I, et al. Tumor budding score based on 10 high-power fields is a promising basis for a standardized prognostic scoring system in stage II colorectal cancer. Hum Pathol (2013) 44:697-705. doi:10.1016/j.humpath.2012.07.026

54. Gockel I, Sgourakis G, Lyros O, Polotzek U, Schimanski CC, Lang H, et al. Risk of lymph node metastasis in submucosal esophageal cancer: a review of surgically resected patients. Expert Rev Gastroenterol Hepatol (2011) 5:371-84. doi:10.1586/egh.11.33

55. Giger OT, Comtesse SC, Lugli A, Zlobec I, Kurrer MO. Intra-tumoral budding in preoperative biopsy specimens predicts lymph node and distant metastasis in patients with colorectal cancer. Mod Pathol (2012) 25:1048-53. doi:10.1038/modpathol.2012.56

56. Zlobec I, Hadrich M, Dawson H, Koelzer VH, Borner M, Mallaev M, et al. Intratumoural budding (ITB) in preoperative biopsies predicts the presence of lymph node and distant metastases in colon and rectal cancer patients. Br J Cancer (2014) 110:1008-13. doi:10.1038/bjc.2013.797

57. Waddell T, Verheij M, Allum W, Cunningham D, Cervantes A, Arnold D, et al. Cancer: ESMO-ESSO-ESTRO clinical practice guidelines for diagnosis, treatment and follow-up. Eur J Surg Oncol (2014) 40:584-91. doi:10.1016/j.ejso. 2013.09.020

58. National Comprehensive Cancer Network Proceedings. NCCN practice guidelines for upper gastrointestinal carcinomas. Oncology (1998) 12: 179-223.

59. Strong VE, D'Amico TA, Kleinberg L, Ajani J. Impact of the 7th Edition AJCC staging classification on the NCCN clinical practice guidelines in oncology for gastric and esophageal cancers. J Natl Compr Canc Netw (2013) 11:60-6.

60. Macdonald JS, Smalley SR, Benedetti J, Hundahl SA, Estes NC, Stemmermann $\mathrm{GN}$, et al. Chemoradiotherapy after surgery compared with surgery alone for adenocarcinoma of the stomach or gastroesophageal junction. $\mathrm{N} \mathrm{Engl} \mathrm{J} \mathrm{Med}$ (2001) 345:725-30. doi:10.1056/NEJMoa010187 
61. Smit MA, Geiger TR, Song JY, Gitelman I, Peeper DS. A Twist-Snail axis critical for TrkB-induced epithelial-mesenchymal transition-like transformation, anoikis resistance, and metastasis. Mol Cell Biol (2009) 29:3722-37. doi:10.1128/MCB.01164-08

62. Tanaka K, MohriY, Nishioka J, Ohi M, Yokoe T, Miki C, et al. Neurotrophic receptor, tropomyosin-related kinase $\mathrm{B}$, as a chemoresistant marker in oesophageal cancer. Clin Oncol (2009) 21:362-3. doi:10.1016/j.clon.2009.01.002

63. Guilford P, Hopkins J, Harraway J, McLeod M, McLeod N, Harawira P, et al. E-cadherin germline mutations in familial gastric cancer. Nature (1998) 392:402-5. doi:10.1038/32918

64. Jass JR, Atkin WS, Cuzick J, Bussey HJ, Morson BC, Northover JM, et al. The grading of rectal cancer: historical perspectives and a multivariate analysis of 447 cases. Histopathology (1986) 10:437-59. doi:10.1111/j.1365-2559.1986. tb02497.x

65. Jass JR, Love SB, Northover JM. A new prognostic classification of rectal cancer. Lancet (1987) 1:1303-6. doi:10.1016/S0140-6736(87)90552-6

66. Ohtsuki K, Koyama F, Tamura T, Enomoto Y, Fujii H, Mukogawa T, et al. Prognostic value of immunohistochemical analysis of tumor budding in colorectal carcinoma. Anticancer Res (2008) 28:1831-6.
67. Caie PD, Turnbull AK, Farrington SM, Oniscu A, Harrison DJ. Quantification of tumour budding, lymphatic vessel density and invasion through image analysis in colorectal cancer. J Transl Med (2014) 12:156. doi:10.1186/1479-5876-12-156

Conflict of Interest Statement: The authors declare that the research was conducted in the absence of any commercial or financial relationships that could be construed as a potential conflict of interest.

Received: 02 July 2014; accepted: 29 July 2014; published online: 14 August 2014. Citation: Koelzer VH, Langer R, Zlobec I and Lugli A (2014) Tumor budding in upper gastrointestinal carcinomas. Front. Oncol. 4:216. doi: 10.3389/fonc.2014.00216

This article was submitted to Gastrointestinal Cancers, a section of the journal Frontiers in Oncology.

Copyright (c) 2014 Koelzer, Langer, Zlobec and Lugli. This is an open-access article distributed under the terms of the Creative Commons Attribution License (CC BY). The use, distribution or reproduction in other forums is permitted, provided the original author(s) or licensor are credited and that the original publication in this journal is cited, in accordance with accepted academic practice. No use, distribution or reproduction is permitted which does not comply with these terms. 